\title{
Lipomatous Lumbar Mass with an Attached Digit and Associated Split Cord Malformation
}

\author{
CMH Snelling, PM Ellis, RML Smith, JP Rossiter
}

\begin{abstract}
Background: A male infant was born with a digit attached to a skin-covered lumbar lipomatous mass and an underlying split cord malformation. Methods: Surgical removal of the mass was performed at four months-of-age. By this time the digit had grown a nail and imaging and histology showed ongoing development of articulated phalanges. Results: The lipomatous mass contained a long bone, a clavicle- and scapula-like structure and a variety of other mature germ layer derivatives. These features raised a number of diagnostic considerations, including: mature teratoma, hamartoma, rudimentary parasitic twin, lipomyelomeningocele and dorsal accessory limb. Conclusions: Based on review of the literature, the authors hypothesize that there is a pathogenetically related spectrum of skincovered dorsal mass lesions, often associated with spinal dysraphism. These consist of a major lipomatous component and a variety of mature germ layer derivatives that can vary widely in their degree of anatomical organization from case to case.
\end{abstract}

RÉSUMÉ: Masse lombaire lipomateuse avec appendice digital et malformation de la moelle épinière. Contexte : À la naissance, on a constaté chez un bébé de sexe masculin la présence d'un doigt fixé à une masse lipomateuse recouverte de peau à la région lombaire et d'une malformation sous-jacente de la moelle épinière. Méthodes : On a procédé à une exérèse chirurgicale de la masse lorsque le bébé était âgé de quatre mois. Un ongle avait poussé sur le doigt et des phalanges articulées en développement étaient visibles à l'imagerie ainsi qu'à l'histologie. Résultats : La masse lipomateuse contenait un os long, des structures ressemblant à une clavicule et à une omoplate ainsi que d'autres structures matures, dérivées des feuillets embryonnaires. Plusieurs diagnostics ont été considérés : un tératome mature, un hamartome, un jumeau parasite rudimentaire, un lipomyéloméningocèle et un membre dorsal accessoire. Conclusions : Après révision de la littérature, les auteurs ont émis l'hypothèse qu'il existe une gamme de masses dorsales recouvertes de peau qui sont reliées au point de vue pathogénique et souvent associées à une myélodysraphie. Elles sont constituées d'une composante lipomateuse importante et de structures matures variées, dérivées des feuillets embryonnaires, dont l'organisation anatomique varie considérablement d'un cas à l'autre.

Can. J. Neurol. Sci. 2008; 35:250-254

A variety of skin-covered dorsal masses associated with spinal dysraphism have been described in the literature, including: lipoma, ${ }^{1,2}$ lipomyelomeningocele ${ }^{3}$ and more anatomically complex lesions that have been variably classified as spinal hamartomas, ${ }^{4,5}$ mature teratomas, ${ }^{6-9}$ midline dorsal appendages, ${ }^{10}$ dorsal accessory limbs ${ }^{11-13}$ and poorly organized parasitic twins.${ }^{14}$ Here we present the case of an infant born with a lipomatous lumbar mass with an attached digit and an underlying split cord malformation. The differential diagnosis of this complex is briefly discussed in relation to the categories outlined above. A unifying hypothesis for this otherwise apparently disparate group of lesions is proposed. This case has previously been presented in abstract form. ${ }^{15}$

From the Department of Pathology and Molecular Medicine (CMHS, JPR),

Department of Surgery, Division of Neurosurgery (PME), and Department of Radiology (RMLS), Queen's University and Kingston General Hospital, Kingston, Ontario, Canada.

Received OCtober 25, 2007. Final Revisions Submitted DeCember 18, 2007 Reprint requests to: John. P. Rossiter, Department of Pathology and Molecular Medicine, Queen's University and Kingston General Hospital, Richardson Laboratory, Room 201, Queen's University, Kingston, Ontario, K7L 3N6, Canada. 


\section{Case Report}

History. A gravida 3 para 2, 20-year-old woman initially presented at 19 weeks 5 days gestation, when an obstetric ultrasound examination showed a possible fetal meningomyelocele. The pregnancy to that point had been uncomplicated, although folic acid had not been taken prior to conception and maternal serum screening had not been performed. The mother denied the use of alcohol or illicit drugs during pregnancy, but smoked a half pack of cigarettes per day. Her existing two children were healthy and there was no maternal or paternal family history of neural tube defects.

Physical exam and imaging. At 30 weeks 0 days, ultrasound examination showed a male fetus with normal cranial anatomy, but confirmed a vertebral abnormality with an overlying cystic and solid mass in the lumbar area. The infant was born prematurely at 34 weeks 5 days gestation in an uncomplicated vaginal delivery, with Apgar scores of 9 and 9. His weight, length and head circumference measurements were approximately on the 50th percentile for his gestational age. Cytogenetic analysis subsequently showed a normal 46XY karyotype. At birth the infant moved all four limbs normally and displayed normal reflexes. He was found to have retrognathia, a high arched palate, posteriorly set ears, and a simian crease on the palm of his right hand. There was a $4 \times 4 \times 2 \mathrm{~cm}$ skin covered midline mass over the upper lumbar spine. A $3.5 \times 1 \mathrm{~cm}$ digit-like structure was attached to the right lateral aspect of the mass, with its long axis oriented rostro-laterally. There was a $1 \mathrm{~cm}$ Mongolian blue spot on the right buttock. The physical examination was otherwise unremarkable.

Computed tomography and magnetic resonance imaging (Figure 1) of the spine showed dysraphism at the thoracolumbar
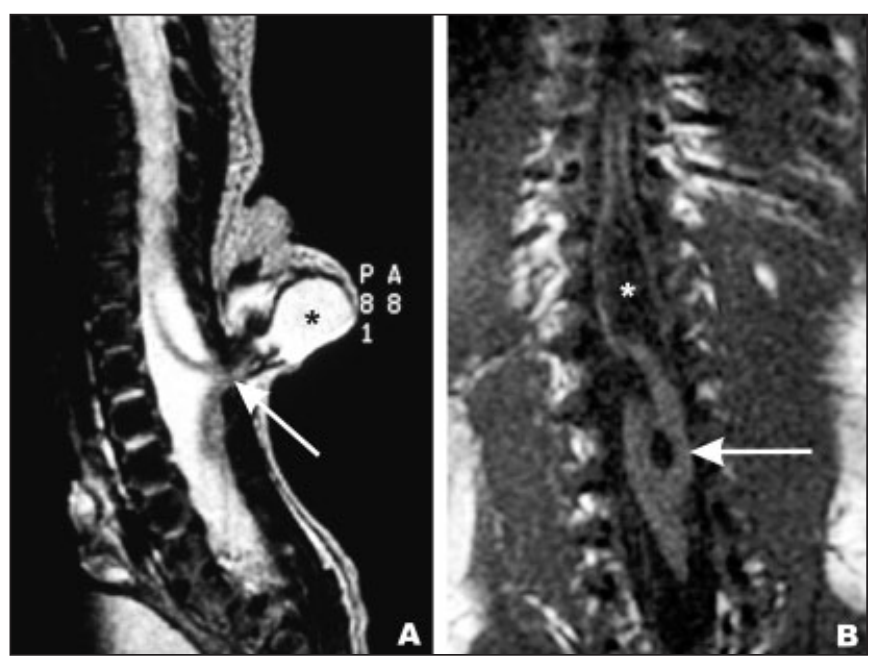

Figure 1: A) A sagittal T-2 weighted MRI of the thoracolumbar spine shows hydromyelia and posterior tethering of the cord (arrow) at L1/2, adjacent to a CSF filled cyst (asterisk) within the lumbar mass. B) A coronal T-1 weighted image of the thoracolumbar spine shows hydromyelia (asterisk), and a split-cord malformation at the L4 level (arrow). junction, with widening of the posterior elements of T12, L1 and L2, posterior tethering of the cord and hydromyelia extending above and below the level of the vertebral defects. The dorsal mass was continuous with the dysraphism and contained fat, soft tissue and boney elements. A cerebro-spinal fluid filled cyst within the mass communicated with the hydromyelia. There was a split cord malformation at L4. Cranial and cervical imaging was unremarkable, with no evidence of hydrocephalus or Arnold-Chiari malformation.

Since the spinal lesion was skin covered and the infant neurologically intact, surgery was deferred until four months-ofage, in order that he could gain weight and recover from anemia of prematurity. By this time the digit had grown a nail, which had not been present at birth (Figures 2 and 3A). Serial imaging of the digit showed growth of the phalanges, with their lengths being very similar to those of the little finger of the infant's right hand. Surgery. Following an elliptical skin incision, much of

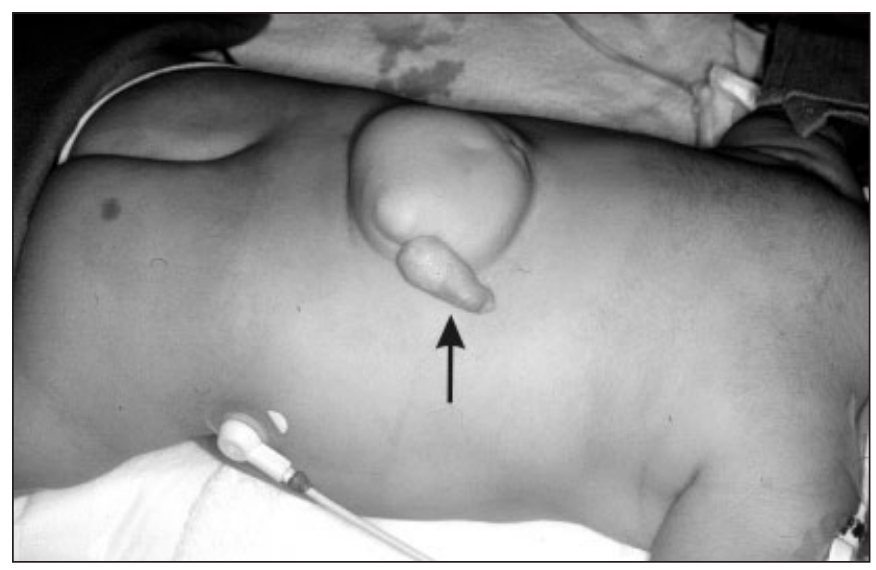

Figure 2: The skin-covered lumbar mass with an attached digit (arrow) seen preoperatively at four months-of-age.

the lumbar subcutaneous mass was found to be composed of fibro-fatty tissue. With dissection, a $1.5 \mathrm{~cm}$ diameter meningocele sac was identified emerging through a defect in the posterior vertebral elements at an upper lumbar level. Boney tissue extended from the region of a deformed lamina on the left side into the overlying adipose tissue. A sinus tract was identified on the right side of the mass. On probing, this was found to connect a mucocele sac with a previously unidentified small orifice on the skin surface, and the entire tract was excised. Following exploration of the dural sac and release of a dorsally tethered Type II $^{16}$ split cord malformation (two hemicords within a single dural tube), the sac was excised and the dura closed.

Pathology. The resected specimen (Figure 3A) consisted of a skin-covered mass of adipose tissue with a digit $(4 \mathrm{~cm}$ in length and $1.6 \mathrm{~cm}$ in greatest diameter) attached to it by a short pedicle 

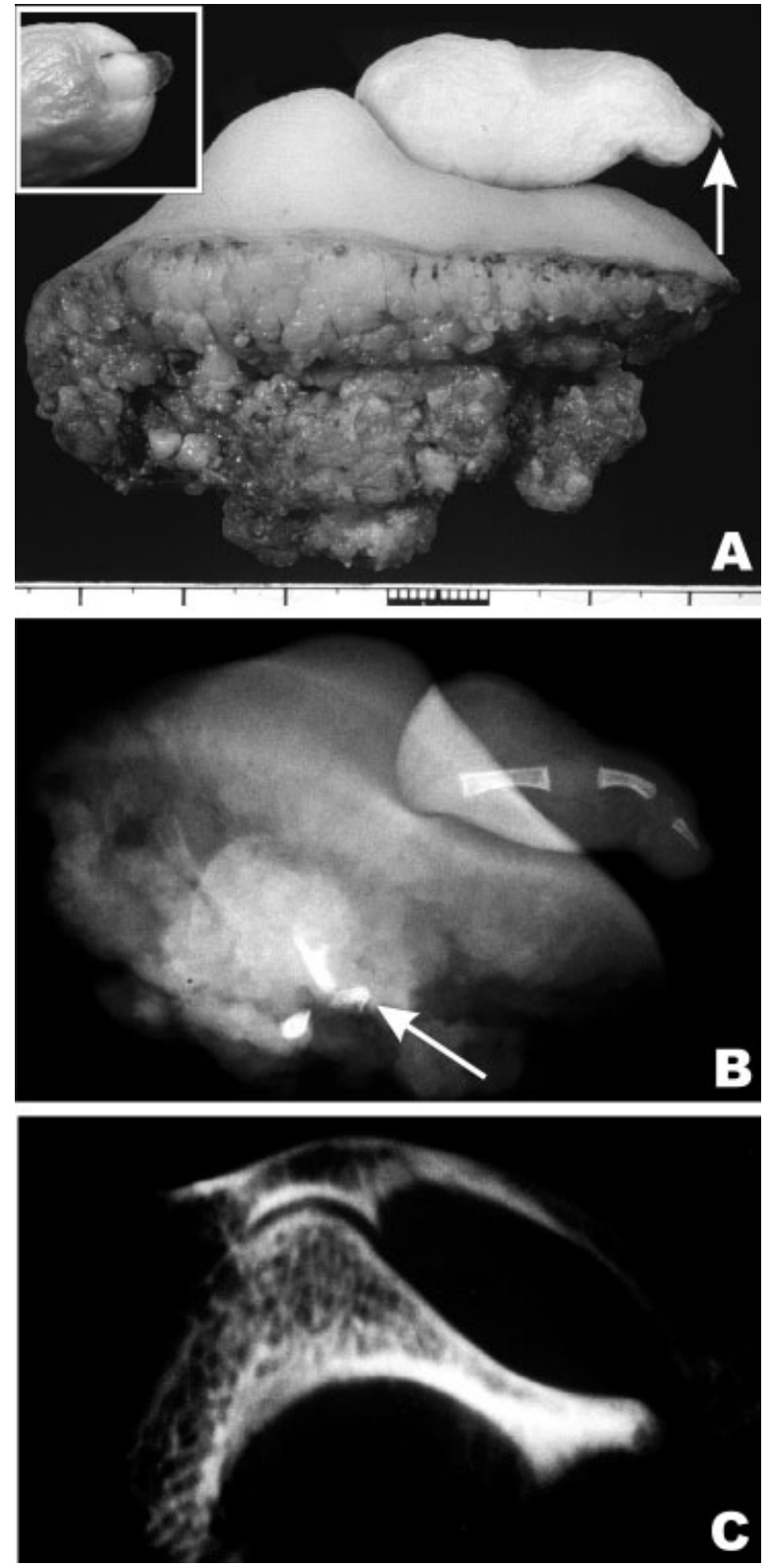

Figure 3: A) A right lateral view of the resected lumbar mass, showing the digit and underlying fibroadipose tissue. The nail (arrow), which had not been visible at birth, is shown in more detail in the inset. B) A radiograph of the resected specimen shows articulated phalanges and other boney tissue (arrow). C) A radiograph of a rudimentary articulated clavicle-and scapula-like structure $(2.1 \times 1.7 \times 0.8 \mathrm{~cm})$ found within the deeper part of the mass.

$(0.1 \mathrm{~cm}$ in length and $0.7 \mathrm{~cm}$ in diameter $)$. An X-ray of the specimen showed well-formed phalanges and irregular masses of boney tissue near the deep resection margin (Figure 3B). A longitudinal section of the digit showed articulated phalanges, skin appendages and a well developed nail bed. The lumbar mass was composed predominantly of mature yellow fat. Dissection and radiography of the bony tissue embedded within this fat revealed an articulated clavicle- and scapula-like structure (2.1 $\mathrm{cm}$ ) (Figure $3 \mathrm{C})$, a rudimentary long bone $(0.8 \mathrm{~cm})$, and an irregular mass of bone and bone marrow $(0.5 \mathrm{~cm})$.

Histologically, mature derivatives from all three germ layers were identified (Figure 4) intermixed with the fatty tissue, especially on sections from the deeper part of the mass. These tissues included: cartilage, bone and bone marrow, smooth and skeletal muscle (Figure 4A), lymph node with well developed germinal centres (Figure 4B), cystic structures lined by epidermis and respiratory-type epithelium, sero-mucinous glandular tissue (Figure 4C), peripheral nerve bundles and sensory-type ganglia (Figure 4D) and small bands of astroglial tissue. Leptomeningeal tissue, focally covered by dura mater, was also identified in portions of the deeper tissue. No immature tissue elements were identified. Cytogenetic analysis performed on cells cultured from a sample of fresh tissue from the base of the digit showed a normal male karyotype.

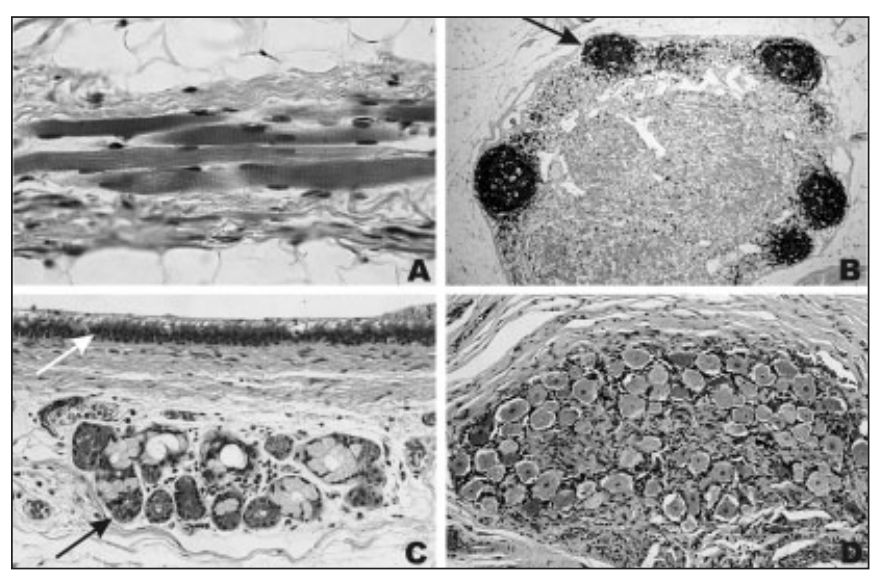

Figure 4: Photomicrographs of representative mature derivatives from all three germ layers within the mass: A) skeletal muscle (x315\}; B) lymph node with germinal centres (arrow) highlighted by immunoperoxidase staining for the pan-B cell marker CD-20. (x40); $C$ ) respiratory-type epithelium (white arrow) and seromucinous glands (black arrow) (x180), and D) a dorsal root ganglion (x110), (A, C\& D, HPS stain).

Postoperative course. The infant was neurologically intact postoperatively, but was subsequently lost to follow-up at the spina bifida clinic. He represented at three years-of-age with paraparesis, chronic constipation and recurrent urinary tract infections, due to a tethered cord and underwent re-exploration of the lesion site with excision of a taut and fibrotic filum terminale. At ten years-of-age this child now attends school and can walk with the assistance of a right sided knee-ankle-foot orthosis, left ankle-foot orthosis and a walker. 


\section{Discussion}

The features of this case - a digit arising from a lumbar lipomatous mass containing mature tissue from all three germ layers and associated with underlying spinal dysraphism - raise a number of diagnostic considerations, as follows. Dysraphismassociated dorsal midline masses containing a variety of welldifferentiated germ layer derivatives have been classified as mature teratomas ${ }^{7-9,17,18}$ or hamartomas.,.$^{4,5}$ Alternatively, it is possible that the digit and mass in the present case represent a rudimentary parasitic/conjoint twin ('rachipagus'19). More complex masses, containing two digits and a thumb, ${ }^{12}$ and a foot, partial leg, finger and penis with a connecting bladder ${ }^{11}$ and associated with thoracic and lumbosacral spinal dysraphism respectively, have been interpreted as parasitic twin phenomena. Similar cases with complex anatomy, including an accessory phallus, testes and scrotum, segments of bowel and bladder and extrophic urinary bladder, have been classified as "disorganizationlike syndrome". ${ }^{20}$ A recent case of an infant with a split cord malformation and a lipomyelomeningocele containing a loop of gut, lymph node, testicular and glial tissue, and with an overlying accessory penis and scrotum, was interpreted as a spinal mature teratoma. ${ }^{9}$

The present case has many of the characteristics of a lipomyelomeningocele ${ }^{3}$ or congenital lumbosacral lipoma. ${ }^{1,2,21,22}$ Histologically, these lesions frequently contain a range of mature germ layer derivatives, ${ }^{1,22,23}$ possibly related to abnormal inductive interactions between the dorsal part of the neural tube and the somite-derived dorsal mesoderm. ${ }^{24}$ These ectopic tissues are typically disorganized, although a rudimentary scapula or pelvis has been described in one case. ${ }^{4}$ Given the presence of a split cord malformation in our case, it is interesting to note that a range of ectodermal, mesodermal and endodermal derivatives can be found histologically in the median septa that divide split cord malformations, including ganglionic, lymphoid, renal and mucosal tissue. ${ }^{16,25}$

Because of the high degree of anatomical organization and postnatal growth of the digit, the present case more closely resembles cases of dorsal accessory appendages / limbs ${ }^{10-13,26}$ associated with spinal dysraphism. In a review of nine such cases, Krishna and $\mathrm{Lal}^{13}$ reported that the dysraphic appendages were fully skin-covered and were typically associated with a lipomyelomeningocele.

There has been considerable debate regarding the pathogenesis of the above range of skin-covered dorsal mass lesions (e.g. see discussions in references.) $)^{7,13,14,21,23,24}$ Krishna and Lal, ${ }^{13}$ building on earlier hypotheses of Gardner ${ }^{27}$ and Egar, ${ }^{28}$ have proposed a secondary neural tube defect, with resulting accumulation and dedifferentiation of cells to form a mesodermal blastema beneath intact ectoderm, giving rise to accessory limbs in association with lipomatous masses and spina bifida. This process would be analogous to limb regeneration in urodele amphibians, which involves self-organization and pattern formation in the regeneration blastema. ${ }^{13,29}$ Koen et $\mathrm{al}^{7}$ have postulated a 'dysembryogenic' mechanism of abnormal inductive interactions involving the caudal cell mass to account for their series of intradural spinal teratomas associated with split cord malformation, myelomeningocele and lipomyelomyelomeningocele. Disruption of secondary neurulation, involving differentiation of the pluripotent tissue of the caudal cell mass, has also been implicated to explain the development of congenital intraspinal lipomas ${ }^{22}$ and lipomyelomeningoceles. ${ }^{30}$ Abnormal upregulation of 'organizer genes' such as Wnt-8c at earlier (gastrulation or primitive streak) stages of development has been postulated to underlie conjoined twinning and true duplication of the spinal cord (diplomyelia). ${ }^{31}$

\section{Conclusions}

Based on our review of the above literature, we hypothesize that there is a pathogenetically related spectrum of skin-covered dorsal mass lesions, frequently associated with spinal dysraphism. These lesions consist of a major lipomatous component and a variety of ectodermal, endodermal and mesodermal derivatives (potentially of neural crest origin, given its pluri-potency as a postulated 'fourth germ layer' ${ }^{32}$ ) that vary in their degree of anatomical organization. At one end of the spectrum are lipomas / lipomyelomeningoceles that contain histologically mature but anatomically disorganized germ layer derivatives (variably classified in the literature as spinal lipomas, lipomyelomeningoceles, mature teratomas and hamartomas). At the other end of the spectrum are lesions comprised of welldeveloped limbs, abdomino-pelvic viscera and genitalia (variably interpreted in the literature as mature teratomas, 'rudimentary parasitic/conjoint twin' or 'disorganizationlike syndrome'). The present case occupies an intermediate position along this hypothetical spectrum. Although the etiopathogenesis of these lesions is unclear, their morphological complexity, and in the present case significant postnatal growth of the digit, suggests that they are the outcome of complex midline developmental field defects. ${ }^{33}$

\section{REFERENCES}

1. Walsh JW, Markesbery WR. Histological features of congenital lipomas of the lower spinal canal. J Neurosurg. 1980; 52(4): 564-9.

2. Pierre-Kahn A, Zerah M, Renier D, Cinalli G, Sainte-Rose C, Lellouch-Tubiana A, et al. Congenital lumbosacral lipomas. Childs Nerv Syst. 1997; 13(6): 298-334

3. Sutton LN. Lipomyelomeningocele. Neurosurg Clin N Am. 1995; 6(2): 325-38

4. Tibbs PA, James HE, Rorke LB, Schut L, Bruce DA. Midline hamartomas masquerading as meningomyeloceles or teratomas in the newborn infant. J Pediatr. 1976; 89(6): 928-33.

5. Morris GF, Murphy K, Rorke LB, James HE. Spinal hamartomas: a distinct clinical entity. J Neurosurg. 1998; 88(6): 954-7.

6. Parizek J, Nemecek S, Pospisilova B, Prochazkova O, Nemeckova $\mathrm{J}$, Cernoch Z, et al. Mature sacrococcygeal teratoma containing the lower half of a human body. Childs Nerv Syst. 1992; 8(2): 108-10.

7. Koen JL, McLendon RE, George TM. Intradural spinal teratoma: evidence for a dysembryogenic origin. Report of four cases. J Neurosurg. 1998; 89(5): 844-51.

8. Hamada H, Kurimoto M, Hayashi N, Hirashima Y, Matsumura N, Endo S. Intramedullary spinal teratoma with spina bifida. Childs Nerv Syst. 2001; 17(1-2): 109-11.

9. Vaishya S, Pandey P. Unusual spinal teratoma with an accessory penis on the back. Childs Nerv Syst. 2006; 22(4): 440-3.

10. Fulmer BB, Wilkins RH, Oakes WJ, Filston HC. Midline dorsal appendages. Pediatr Neurosurg. 1997; 27(5): 242-5.

11. Parkinson D. Accessory limbs and spinal dysraphism. J Neurosurg. 1991; 75(3): 498-9.

12. Humphreys RP, Manwaring KH, Carroll NC. Accessory arm dysraphism or disparity? Case report. J Neurosurg. 1991; 74(3): 297-300. 
13. Krishna A, Lal P. Accessory limbs associated with spina bifida - a second look. Pediatr Surg Int. 1999; 15(3-4): 248-250.

14. Drut R, Garcia C, Drut RM. Poorly organized parasitic conjoined twins: report of four cases. Pediatr Pathol. 1992; 12(5): 691-700.

15. Rossiter JP, Kydd DW, Ellis PM, Smith R, Sauerbrei E. Digitbearing lumbar mass with spinal dysraphism. J Neuropathol Exper Neurol. 1998; 57(5): 484, Abstract 62.

16. Pang D, Dias MS, Ahab-Barmada M. Split cord malformation: part I: a unified theory of embryogenesis for double spinal cord malformations. Neurosurgery. 1992;31(3): 451-80.

17. Bucy PC, Haymond HE. Lumbosacral teratoma associated with spina bifida occulta. Am J Pathol. 1932; 8: 339-46.

18. Muthukumar N. Split cord malformation and cystic teratoma masquerading as lipomeningomyelocele. Childs Nerv Syst. 2003; 19(1): 46-9.

19. Spencer R. Parasitic conjoined twins: external, internal (fetuses in fetu and teratomas), and detached (acardiacs). Clin Anat. 2001; 14(6): 428-44.

20. Ilkehan H, Coban YK, Guven MA, Ceylaner, S. Three new cases of disorganizationlike syndrome: one with accessory extrophia vesicalis. J Pediatr Surg. 2004; 39(9): e6-e8.

21. Chapman P, Stieg PE, Magge S, Barnes P, Feany M. Spinal lipoma controversy. Neurosurgery. 1999; 44(1): 186-92.

22. Lellouch-Tubiana A, Zerah M, Catala M, Brousse N, Kahn AP. Congenital intraspinal lipomas: histological analysis of 234 cases and review of the literature. Pediatr Dev Pathol. 1999; 2(4): 346-52.

23. Lemire RJ, Beckwith JB. Pathogenesis of congenital tumors and malformations of the sacrococcygeal region. Teratology. 1982; 25(2): 201-13.
24. Catala M. Embryogenesis. Why do we need a new explanation for the emergence of spina bifida with lipoma? Childs Nerv Syst. 1997; 13(6): 336-40.

25. Ersahin Y, Mutluer S, Kocaman S, Demirtas E. Split spinal cord malformations in children. J Neurosurg. 1998; 88(1): 57-65.

26. Gamanagatti S, Garg R, Srivastava DN, Gupta A, Aggarwal S. Spinal dysraphism with accessory thigh. Pediatr Radiol. 2003; 33(11): 809-10.

27. Gardner WJ. Hypothesis; overdistention of the neural tube may cause anomalies of non-neural organs. Teratology. 1980; 22(2): 229-38.

28. Egar MW. Accessory limb production by nerve-induced cell proliferation. Anat Rec. 1988; 221(1): 550-64.

29. Nye HL, Cameron JA, Chernoff EA, Stocum DL. Regeneration of the urodele limb: a review. Dev Dyn. 2003; 226(2): 280-94.

30. Solanki GA, Evans J, Copp A, Thompson DN. Multiple coexistent dysraphic pathologies. Childs Nerv Syst. 2003; 19(5-6): 376-9.

31. Sarnat HB. Molecular genetic classification of central nervous system malformations. J Child Neurol. 2000; 15(10): 675-87.

32. Vickaryous MK, Hall BK. Human cell type diversity, evolution, development, and classification with special reference to cells derived from the neural crest. Biol Rev Camb Philos Soc. 2006; 81(3): 425-55.

33. Martinez-Frias ML, Frias JL, Opitz JM. Errors of morphogenesis and developmental field theory. Am J Med Genet. 1998; 76(4): 291-6. 